\title{
Do Islamic Bank Assets Help Reducing Poverty? The Correlation Assessment in Poverty Cluster
}

\author{
Muhammad Muflih \\ Politeknik Negeri Bandung, Bandung, Indonesia \\ email:m.muflih@polban.ac.id
}

\begin{abstract}
The purpose of this research is to examine the ability of total assets, deposit funds, and financing of Islamic banks in alleviating poverty in each province. Provincial clusters were measured by poverty levels which are deliberately established to reveal the level of success of each provincial cluster in reducing poverty. This study incorporates methods of hierarchical cluster and non-parametric correlation as means of exposing characters of the relationship between Islamic bank assets and poverty in each cluster measured by low, moderate, and high poverty levels. To refine the findings, correlation tests are performed on each cluster. This study proves that total assets, deposit funds, and Islamic bank financing have a significant negative relationship with poverty in clusters with high poverty level. On the other hand, in clusters with moderate and low poverty levels, the three variables do not have significant negative relationship with poverty. The finding implies the importance of Islamic banks to map the poverty weights in each group of regions so that it can be used to improve the level of poverty alleviation success.
\end{abstract}

Keywords: Islamic bank; total assets; deposit funds; financing; poverty.

\begin{abstract}
Abstrak: Penelitian ini bertujuan untuk menguji kemampuan total aset, dana pihak ketiga, dan pembiayaan bank syariah mengentaskan kemiskinan di setiap provinsi. Kluster provinsi yang diukur menurut tingkat kemiskinan untuk mengungkap level keberhasilan setiap kelompok dalam mengurangi angka kemiskinan. Penelitian ini memadukan metode kluster hirarki dan korelasi nonparametrik sebagai alat untuk mengungkap karakter hubungan aset-aset bank syariah dan kemiskinan. Untuk mempertajam temuan, uji korelasi dilakukan terhadap masing-masing kluster. Penelitian ini membuktikan bahwa total aset, dana pihak ketiga, dan pembiayaan bank syariah memiliki hubungan negatif signifikan dengan kemiskinan pada kluster yang tingkat kemiskinannya tinggi. Sedangkan pada kluster yang tingkat kemiskinannya sedang dan rendah, ketiga variabel tersebut tidak memiliki hubungan negatif signifikan dengan kemiskinan. Temuan ini mengimplikasikan pentingnya bank syariah memetakan bobot kemiskinan di setiap kelompok daerah sehingga dapat digunakan untuk meningkatkan level keberhasilan pengentasan kemiskinan.
\end{abstract}

Kata Kunci: Bank syariah; total aset; deposito syariah; pembiayaan; kemiskinan

Economica: Jurnal Ekonomi Islam - Volume 10, Nomor 2 (2019) 
Muhammad Muflih

\section{Introduction}

The assets accumulated in Islamic bank have the ability to overcome the problem of poverty (Boukhatem and Ben Moussa, 2018). Through strong Islamic bank assets, a number of industrial sectors will move to boost the economy (Hassan, 2015) and also generate opportunities of developing new industrial sectors (Adnan and Ajija, 2015). It will result in positive effects in which employment increases and everyone's income is sufficient (Hassan and Harahap, 2010). However, the level of poverty in Indonesia of 18.36\% (BPS, 2017) in the last one year is worrying and able to reverse the situation. The high level of poverty generates a question whether Islamic bank has helped much in the poverty alleviation. The lack of breakthrough in the utilization of Islamic bank assets is very likely to trigger the emergence of the poverty problem. Poverty will get strong if the assets of Islamic banks are weak and poverty will get weak if the assets of Islamic banks are strong.

The majority of researchers have devoted their attention to the relationship between Islamic microfinance institutions and poverty (Rahman, 2010; Rashidah and Faisal, 2013; Hassan, 2014; Akhyar et al., 2015). However, it is difficult to find those focusing their attention on the ability of Islamic bank assets in answering this problem. It is because Islamic micro finance products relate directly to bases of poverty (Abbas and Shirazi, 2015). Eventhough, Islamic bank has ability to reach the poor widely (Amin et al., 2011). If the role of Islamic bank assets is being ignored, the public cannot identify the effectiveness of any value of funds collected in answering social inequality problem in community (Aziz and Bin Mohamad, 2016). As a result, the public does not have clear references to social investment. Moreover, by only using qualitative methods (Dusuki, 2008; Suzuki and Miah, 2016), research on Islamic poverty alleviation is less sharp in alleviating the real poverty.

In order to highlight the shape of Indonesia's poverty in more detail, this study divided the provinces into three clusters of poverty. They are low, 
moderate and high poverty clusters. Provincial clustering by poverty level is needed to reveal the correlation characteristics between poverty and Islamic bank assets in each provincial group. Different levels of correlation are very likely to occur because Islamic bank will always adjust the form of challenge in each province (Shahinpoor, 2009). If high poverty continues to occur, it means that Islamic bank needs to change its assets utilization strategies (Kamla and Hussain, 2013). That is why the achievement of social performance of Islamic bank is very dependent on the social and economic typically faced in every province.

This study has three objectives: (1) establishing provincial clusters based on the number of poor people, (2) uncovering the correlation between total assets, deposit funds, and financing of Islamic banks and the number of the poor in each cluster and (3) increasing the success level of each province cluster in addressing the issue of poverty. Through these findings, each Islamic bank can evaluate its ability to overcome poverty according to the conditions occurred in the cluster it is located.

\section{Literature review}

\section{Total assets of islamic bank, poverty and province}

The ability of total assets of Islamic financial institutions in handling the poverty issues has been explained by experts in various ways. Hasan \& Harahap (2010) and Nusrate \& Osman (2016) observed the capability from corporate social responsibility (CSR) point of view. The result of their research indicated that the effectiveness of poverty alleviation cannot be directly felt through total assets but by allocating part of it in CSR activities. Meanwhile, Shahinpoor (2009), Rahman (2010), and Hassan (2014) expressed a more optimistic view that the link of total assets to poverty can be realized directly through the microfinance approach. Some research in several countries have proven that microfinance is able to penetrate marginal groups effectively, so that all members of the group gain significant financial capital (Chhibber and 
Nayyar, 2008; Gounder, 2013). Hassan (2015) proposed another way through the establishment of social microfinance corporation (SMC) in Islamic financial institutions. With the full support from Islamic financial institutions, SMC is able to answer the challenges of poverty problems innovatively. The successes of SMC are: (1) the establishment of small firms with high employment, (2) the spread of capital for microentrepreneurs and smallholders, and (3) the development of empowerment programs for the poorest communities. However, all these views assure us that total assets of Islamic banks relates to poverty.

In addition to strong innovations on the use of bank assets, poverty alleviation can also be accelerated through investment strengthening in each province. Wang et al. (2009) is one of the figures supporting this theory. The strong spotlight on the province can overcome the disparities in urban and rural investment (Adjasi and Osei, 2007; Risso and Carrera, 2012). Warr (2000) cautioned that during disparities, national development does not always have a good impact for rural regions. Support for rural regions must be embedded in the strategies of Islamic bank finance. In fact, Dusuki (2008) had assured that Islamic banks will be stronger if they support regional economic progress. Supportive government policies on poverty will further smooth the relationship of these two variables (Rashid and Intartaglia, 2017; Sasmal and Sasmal, 2016).

\section{Review of the component relationships between Islamic bank assets and poverty}

Studies on the capability of Islamic bank asset components in handling poverty issue have been done by experts using various models. Unfortunately, their studies did not discuss all components of Islamic bank assets, namely: (1) savings, (2) accounts receivable, and (3) financing. They merely relied on financing issues. Cebeci and Hassan (2012) is one of the researchers who seriously pursued the issue of musharaka and mudaraba financing. Through 
the social approach of maslaha, he found that the poor can be easily connected with productive capital projects. It is different from murabaha that promote the patterns of individual maslaha. By highlighting the small and medium business community, Pratiwi (2016) also found the similar point of view. Her research proved that the reduction of poverty due to the poor becomes a core part of the group of micro, small and medium enterprises (UMKM). Hachicha \& Amar (2015) viewed the ability of Islamic financing from a macro point of view. They examined the contribution of Islamic financing to GDP. The result is very encouraging. It showed that PLS financing is able to increase better GDP whose one of effects is poverty reduction.

Basically, the components of Islamic bank assets and poverty can be attributed to a strong motive. Suzuki \& Miah (2016) tried to link the owners of financing funds and the poor through altruism and reciprocity motives. They found that open relationship in mudharaba financing (profit and loss sharing) is not only able to prevent fraudulent transaction costs, but it is also able to accommodate the innovative spirit of the poor. On the other hand, Kamla \& Hussain (2013) emphasized the Islamic financing through the motive of social justice. This spirit can restore the attitude of a number of inconsistent Islamic banks in improving lives of the poor. These motives can be utilized in developing the relationship between saving, accounts receivable, and Islamic financing and poverty.

\section{Methods}

\section{Data}

Two groups of data were investigated, namely: (1) total assets of Islamic banks published by Financial Service Authority (OJK) and (2) number of poor people published by The Central Statistics Agency (BPS). All the data are from 33 provinces in Indonesia. As investigations were conducted on a single province basis, findings on relationships between Islamic bank assets and poverty are very detailed. It is different from Pratiwi's research (2016) which 
only revealed the relationship between Islamic banks and poverty based on macro data List of the provinces is shown in table 1.

Table 1. Province

\begin{tabular}{lll}
\hline West Java & Riau & North Sulawesi \\
Banten & South Sumatera & Gorontalo \\
DKI Jakarta & Bangka Belitung & West Sulawesi \\
Yogyakarta & Riau Islands & South East Sulawesi \\
Central Java & Lampung & NTB \\
East Java & South Kalimantan & Bali \\
Bengkulu & West Kalimantan & NTT \\
Jambi & East Kalimantan & Maluku \\
Nanggroe Aceh Darussalam & Central Kalimantan & Papua \\
North Sumatera & Central Sulawesi & North Maluku \\
West Sumatera & South Sulawesi & West Papua \\
\hline
\end{tabular}

To achieve the purpose of this study, the data in each province was taken through a purposive sampling system. The prescribed criteria are: (1) the report on the development of Islamic bank assets refers to the data of each province and (2) data reported should be over five years. Based on these criteria, we got data in the period of 8 years, from 2009 to 2016. All the data were compiled according to the poverty level of each provincial cluster.

\section{Variables}

This study examines the relationship between Islamic bank assets and poverty totally and partially. Totally, variables tested are the total assets of Islamic banks and the number of poor people. Partially, this study examines the relationship between (1) the amount of savings and the poor, (2) the number of Islamic bank accounts and the poor, and (3) the number of Islamic bank financing and the poor. The pattern of variable relationships was intentionally created to develop a research conducted by Abbas \& Shirazi (2015), Rahman (2010), and Adnan \& Ajija (2015) showing that their findings 
are too general and have not yet described the changing conditions of regional poverty in detail.

\section{Procedure}

By using PASW Statistics of 18, this study built two analytical procedures, which are: (1) hierarchical cluster analysis and (2) non-parametric correlation analysis. Hierarchical cluster analysis was applied on the data of the number of poor people in each province and it resulted in three provincial clusters with poverty levels of (1) low, (2) moderate, and (3) high. We placed each Islamic bank based on the clusters. The analysis this study is similar to the analysis used by DeLong (2001) and Boyacioglu (2009) which successfully mapped out bank conditions based on regional characteristics. Leuz et al. (2003) have also inspired this study because they have successfully improved the earning management score of a number of countries by cluster size. Using this pattern, we will improve the correlation between Islamic bank assets and poverty in each cluster.

After provincial poverty clusters were formed, we then proceeded to a non-parametric correlation analysis. The correlation model was chosen because we use ordinal data. In practice, the correlation analysis was applied on the clusters one by one to produce a comparative description on each cluster. To complete the information, we use both Spearman and Kendal correlation. Both theories become a reference in the cluster rating.

Hauke \& Kossowski (2011) recognized that non-parametric correlations have an advantage in reading the strengths of two variable relationships whose distribution properties are uncertain. Patro et al. (2013) also believed that non-parametric correlations of Spearman and Kendal that do not depend on certain parameters greatly facilitate the analyst in monitoring changes in economic data over time. These views strongly support the analysis of this study. The model of analysis can accept the difference in the distribution of

Economica: Jurnal Ekonomi Islam - Volume 10, Nomor 2 (2019) 
data to be produced in each provincial poverty cluster. However, this study cannot ensure that the distribution of data on each cluster is the same.

The steps of analyzing of this research are as follows: (1) entering the data of Islamic bank assets into provincial clusters, (2) testing the correlation between Islamic bank assets and poverty in each cluster, and (3) ranking the correlation performance of all clusters.

\section{Results and discussion}

\section{Analysis of hierarchical clusters}

To present descriptive evidences of poverty conditions in provincial groups, the first analysis to be used is the hierarchical cluster analysis. The analysis aims to look for similarities in the character of poverty in every province. The character was measured by the number of poor people. The clusterswere divided into 3 clusters with the category of low, moderate, and high number of the poor. Since the hierarchical cluster analysis is free, it is very likely that the number of members generated on each cluster is different. This approach is very useful in mapping provincial poverty without using a number of assumptions.

The similarity of the poverty level of each province can be seen through the agglomeration schedule in table 2 . The function of the list is to identify contents of the data on the number of poor people from the provinces that begins from the most similar (stage 1) to the most unsimilar (stage 32). The most similar set of data forms a cluster. The most similar provinces are number 1 and 9 (West Java and Aceh). They have a coefficient level of 0,000 with the similar average number of poor people of 899.374 (see table 4). Next, we can read the instruction of next stage on stage 1 which explains that another province whose number is closest to West Java and Aceh is number 22 (South Sulawesi). The average number of the poor in this province is 893.178 people. As the result, three of the provinces are worthy to form a 
Do Islamic Bank Asset Help Reducing...

cluster. If any other province approaches their number then it could be included as a member of that cluster.

Table 2. Agglomeration schedule

\begin{tabular}{|c|c|c|c|c|c|c|}
\hline \multirow[t]{2}{*}{ Stage } & \multicolumn{2}{|c|}{$\begin{array}{l}\text { Cluster } \\
\text { Combined }\end{array}$} & \multirow[t]{2}{*}{ Coefficients } & \multicolumn{2}{|c|}{$\begin{array}{c}\text { Stage Cluster First } \\
\text { Appears }\end{array}$} & \multirow[t]{2}{*}{$\begin{array}{l}\text { Next } \\
\text { Stage }\end{array}$} \\
\hline & C1 & C2 & & C1 & C2 & \\
\hline 1 & 1 & 9 & .000 & 0 & 0 & 18 \\
\hline 2 & 23 & 24 & .000 & 0 & 0 & 6 \\
\hline 3 & 17 & 28 & .001 & 0 & 0 & 6 \\
\hline 4 & 20 & 25 & .002 & 0 & 0 & 9 \\
\hline 5 & 14 & 32 & .002 & 0 & 0 & 22 \\
\hline 6 & 17 & 23 & .003 & 3 & 2 & 15 \\
\hline 7 & 19 & 33 & .004 & 0 & 0 & 14 \\
\hline 8 & 26 & 30 & .006 & 0 & 0 & 12 \\
\hline 9 & 15 & 20 & .007 & 0 & 4 & 15 \\
\hline 10 & 11 & 18 & .007 & 0 & 0 & 11 \\
\hline 11 & 11 & 21 & .009 & 10 & 0 & 19 \\
\hline 12 & 7 & 26 & .013 & 0 & 8 & 17 \\
\hline 13 & 22 & 27 & .015 & 0 & 0 & 18 \\
\hline 14 & 8 & 19 & .016 & 0 & 7 & 20 \\
\hline 15 & 15 & 17 & .020 & 9 & 6 & 20 \\
\hline 16 & 4 & 12 & .022 & 0 & 0 & 24 \\
\hline 17 & 3 & 7 & .023 & 0 & 12 & 19 \\
\hline 18 & 1 & 22 & .030 & 1 & 13 & 23 \\
\hline 19 & 3 & 11 & .048 & 17 & 11 & 24 \\
\hline 20 & 8 & 15 & .050 & 14 & 15 & 22 \\
\hline 21 & 13 & 29 & .068 & 0 & 0 & 29 \\
\hline 22 & 8 & 14 & .110 & 20 & 5 & 28 \\
\hline 23 & 1 & 31 & .171 & 18 & 0 & 25 \\
\hline 24 & 3 & 4 & .185 & 19 & 16 & 28 \\
\hline 25 & 1 & 2 & .261 & 23 & 0 & 29 \\
\hline 26 & 10 & 16 & .303 & 0 & 0 & 30 \\
\hline 27 & 5 & 6 & .444 & 0 & 0 & 32 \\
\hline 28 & 3 & 8 & .450 & 24 & 22 & 31 \\
\hline 29 & 1 & 13 & .488 & 25 & 21 & 30 \\
\hline 30 & 1 & 10 & 1.762 & 29 & 26 & 31 \\
\hline 31 & 1 & 3 & 4.177 & 30 & 28 & 32 \\
\hline 32 & 1 & 5 & 154.681 & 31 & 27 & 0 \\
\hline
\end{tabular}

Economica: Jurnal Ekonomi Islam - Volume 10, Nomor 2 (2019) 
Entering stage 2, it is found that province of 23 (North Sulawesi) is identical to number 24 (Gorontalo) whose coefficient values are 0.000 . Their average numbers of poor people respectively are 208,771 and 208,510. Being stated in the next stage instruction, another identical province is number 17 (South Kalimantan), which has an average number of the poor of 194,700 people. In fact, when they were tested using coefficient value, the result is 0.003 showing a good result. However, the average number of poor people in these three provinces is very different from the cluster 1 consisting West Java and friends. Consequently, the clusters to be formed must be different from the cluster 1.

In stage 27, table 2 also shows the similarities between province number 5 (Central Java) and 6 (East Java) whose coefficients are 0.444. Unfortunately, the similar number that resembles their coefficient cannot be found in the instruction of 'next stage'. The coefficient value displayed on the instructions of the next stage is the coefficient of stage 32 of 154.681 . This coefficient value is the worst. It signifies that province 1 (West Java) is very different from province 5 (Central Java). Table 4 proves the condition showing that the average numbers of the poor from each province respectively are 899,374 and 5,238,624 people. Therefore, Central Java and East Java will form the most unsimilar cluster. After stage 32, no new clusters can be formed.

Cluster formation of provincial poverty can be seen in table 3 consisting of 3 clusters in which cluster 1 has 10 members, cluster 2 has 21 members, and cluster 3 has 2 members. The difference in the number of cluster members is due to the differences in the poverty character of each province. Looking at the fact, it can be concluded that the differences and similarities of the number of poor communities in the Indonesian provinces have exceeded geographical boundaries. In this case, for example, West Java which is located on the island of Java is the same as Aceh which is located on the island of Sumatra. However, West Java is far different from Jakarta whereas their location geographically are very close each other. 
Tabel 3. Cluster formation for province poverty

\begin{tabular}{llll}
\hline Clusters & & \multicolumn{1}{c}{ Province } & \\
\hline C1 & (1) West Java & (13) South Sumatera & (29) NTT \\
& (2) Banten & (16) Lampung & (31) Papua \\
& (9) Aceh & (22) South Sulawesi & \\
(10) North Sumatera & (27) NTB & \\
C2 & (3) DKI Jakarta & (15) Riau Islands & (24) Gorontalo \\
& (4) Yogyakarta & (17) South Kalimantan & (25) West Sulawesi \\
& (7) Bengkulu & (18) West Kalimantan & (26) South East \\
& (8) Jambi & (19) East Kalimantan & (28) Bali \\
& (11) West Sumatera & (20) Central Kalimantan & (30) Maluku \\
& (12) Riau & (21) Central Sulawesi & (32) North Maluku \\
& (14) Bangka Belitung & (23) North Sulawesi & (33) West Papua \\
& (5) Central Java & (6) East Java & \\
\hline
\end{tabular}

Table 4 shows the formation of the number of people in each province by cluster. The table consists of: (1) panel A displaying details of poverty data in each province sorted by cluster and (2) panel B displaying a summary of the poverty of each cluster. In panel A, it can be clearly known that in cluster 1 Papua is the province with the lowest number of the poor of 733,100 people. Meanwhile, NTT becomes the province with the highest number of the poor of $1,908,570$ people. The lowest average occurs in Banten province, while the highest average is North Sumatra province. In terms of growth, the province of Papua is the best in this cluster.

Based on the data description of cluster 2, the poverty condition in cluster 2 differs from cluster 1 . In this cluster, the province with the minimum number of poor people is Bangka Belitung. It has only 67,800 poor people. According to its average and growth, Bangka Belitung becomes the best province in this cluster. In contrast, Yogyakarta with a total of 633,500 poor people has the highest number in this cluster. The average and growth of the number of poor people in Yogyakarta reveals that Yogyakarta is the worst province in this cluster.

Economica: Jurnal Ekonomi Islam - Volume 10, Nomor 2 (2019) https://journal.walisongo.ac.id/index.php/economica 
Muhammad Muflih

Table 4. Province poverty

Panel A: Province poverty by cluster

\begin{tabular}{|c|c|c|c|c|c|}
\hline Cluster & Province & Min & Max & Ave & Growth \\
\hline \multirow[t]{10}{*}{$\mathrm{C} 1$} & West Java & 844,875 & $1,083,700$ & 899,374 & 981,021 \\
\hline & Banten & 636,015 & 886,200 & 725,020 & 832,997 \\
\hline & Aceh & 844,875 & $1,083,700$ & 899,374 & 981,021 \\
\hline & North Sumatera & $1,323,635$ & $1,768,500$ & $1,489,018$ & $1,623,243$ \\
\hline & South Sumatera & $1,057,000$ & $1,331,800$ & $1,143,734$ & $1,232,601$ \\
\hline & Lampung & $1,132,085$ & $1,661,700$ & $1,342,288$ & $1,651,878$ \\
\hline & South Sulawesi & 801,920 & $1,083,400$ & 893,178 & $1,025,688$ \\
\hline & NTB & 795,510 & $1,118,600$ & 923,869 & $1,109,144$ \\
\hline & NTT & 991,880 & $1,908,570$ & $1,162,219$ & $1,128,139$ \\
\hline & Papua & 733,100 & $1,037,670$ & 868,840 & 767,843 \\
\hline \multirow[t]{21}{*}{$\mathrm{C} 2$} & DKI Jakarta & 312,200 & 405,700 & 368,632 & 355,714 \\
\hline & Yogyakarta & 491,885 & 633,500 & 562,868 & 627,706 \\
\hline & Bengkulu & 303,600 & 370,600 & 328,446 & 343,294 \\
\hline & Jambi & 241,600 & 306,135 & 272,015 & 255,548 \\
\hline & West Sumatera & 364,570 & 529,200 & 420,872 & 494,416 \\
\hline & Riau & 482,050 & 574,500 & 518,389 & 541,187 \\
\hline & Bangka Belitung & 67,800 & 95,100 & 75,083 & 84,144 \\
\hline & Riau Islands & 118,615 & 148,400 & 129,368 & 140,409 \\
\hline & South Kalimantan & 176,000 & 233,500 & 194,700 & 207,403 \\
\hline & West Kalimantan & 359,500 & 584,300 & 425,006 & 501,123 \\
\hline & East Kalimantan & 211,440 & 324,800 & 251,460 & 290,947 \\
\hline & Central Kalimantan & 140,475 & 210,300 & 160,938 & 191,805 \\
\hline & Central Sulawesi & 389,855 & 557,400 & 450,806 & 526,323 \\
\hline & North Sulawesi & 183,300 & 250,100 & 208,771 & 225,490 \\
\hline & Gorontalo & 187,300 & 241,900 & 208,510 & 225,747 \\
\hline & West Sulawesi & 141,300 & 189,900 & 160,096 & 171,515 \\
\hline & South East Sulawesi & 310,300 & 465,400 & 367,951 & 443,289 \\
\hline & Bali & 164,900 & 229,100 & 188,194 & 199,646 \\
\hline & Maluku & 311,565 & 404,700 & 355,106 & 401,051 \\
\hline & North Maluku & 75,540 & 109,900 & 91,162 & 108,667 \\
\hline & West Papua & 224,700 & 266,800 & 240,969 & 262,499 \\
\hline \multirow[t]{2}{*}{ C3 } & Central Java & $4,500,320$ & $6,557,200$ & $5,238,624$ & $6,282,795$ \\
\hline & East Java & $4,670,915$ & $7,155,300$ & $5,482,532$ & $6,708,250$ \\
\hline
\end{tabular}


Do Islamic Bank Asset Help Reducing...

Panel B: Poverty by cluster

\begin{tabular}{lcrrrr}
\hline Cluster & Province & \multicolumn{1}{c}{ Min } & \multicolumn{1}{c}{ Max } & \multicolumn{1}{c}{ Ave } & \multicolumn{1}{c}{ Growth } \\
\hline C1 & 10 & 636,015 & $1,908,570$ & $1,034,691$ & $1,133,358$ \\
C2 & 21 & 67,800 & 633,500 & 284,730 & 314,187 \\
C3 & 2 & $4,500,320$ & $7,155,300$ & $5,360,578$ & $6,495,523$ \\
\hline
\end{tabular}

Drastic differences can be observed in cluster 3. Panel A clearly shows that the whole description in cluster 3 is the worst among all clusters because the minimum number in this cluster is much higher than the other provinces.

Brief description of each cluster condition is provided one by one in panel B. The lowest poverty is experienced by cluster 2, because it has an average of the poor of 284,730. Meanwhile, cluster 1 is categorized as moderate because it has an average of the poor of $1,034,691$. The highest poverty occurs in cluster 3 with the average of the poor of 5,360,578 people. Although cluster 3 is the highest among all clusters, it does not mean that clusters 1 and 2 are safe from the poverty traps by reason of the average growth of the number of the poor in cluster 2 has reached 314,187 people, even in cluster 1 it exceeds $1,000,000$ people.

\section{Descriptive statistics of islamic bank assets}

Descriptive statistics of total assets, financing, and deposit funds are shown in table 5. Different descriptions of those variables on each cluster can be observed using the table. The study observed 80 data of Islamic bank assets in cluster 1, 168 data of Islamic bank assets in cluster 2 and 16 Islamic bank data in cluster 3. In terms of assets, the lowest total assets are found in cluster 2 as much as 9.9 billion IDR. The highest minimum asset of 3.9 trillion IDR is obtained in cluster 3 . The lowest maximum asset belongs to cluster 3 owning 29.6 trillion IDR. The highest maximum asset is found in cluster 2 that is 257.19 trillion IDR. However, based on average number, cluster 3 becomes the best cluster having total assets of 16.77 trillion IDR. According to their standard deviation, cluster 2 is the best of all clusters because its standard

Economica: Jurnal Ekonomi Islam - Volume 10, Nomor 2 (2019) https://journal.walisongo.ac.id/index.php/economica 
Muhammad Muflih

deviation is only 3.7. It indicates that the total asset values in each province coming from cluster 2 are close to each other. However, the standard deviation figures cannot be claimed as the determinant of the best total asset performance of all clusters.

Table 5. Descriptive statistic of total asset, financing, and depositor funds (in million)

\begin{tabular}{lllcccc}
\hline Cluster & Variable & Min & Max & Ave & SD & N \\
\hline C1 & Total asset & 37,000 & $44,933,000$ & $6,618,737$ & 9.30 & 80 \\
& Financing & 33,000 & $29,851,794$ & $4,339,013$ & 5.95 & 80 \\
& Deposit Funds & 36,000 & $29,563,682$ & $4,108,875$ & 5.88 & 80 \\
& & & & & & \\
C2 & Total asset & 9,000 & $257,195,000$ & $9,584,511$ & 3.79 & 168 \\
& Financing & 109 & $101,540,928$ & $4,052,899$ & 1.43 & 168 \\
& Deposit Funds & 9,000 & $134,736,335$ & $4,685,186$ & 1.84 & 168 \\
& & & & & & \\
C3 & Total asset & $3,924,000$ & $29,683,000$ & $16,775,750$ & 8,79 & 16 \\
& Financing & $2,611,000$ & $21,634,239$ & $11,256,103$ & 6.01 & 16 \\
& Deposit Funds & $2,241,000$ & $21,543,455$ & $10,830,069$ & 6.23 & 16 \\
\hline
\end{tabular}

Table 5 also describes financing conditions of each cluster. The lowest financing is found in cluster 2, while cluster 3 has the highest minimum financing level. However, according to the highest maximum, then cluster 2 is the highest because it has a financing value of 101.5 trillion IDR. Uniquely, the lowest deviation value is also found in cluster 2 with the value of 1.4. It indicates that the gap of inter-provincial financing level in cluster 2 is not too far. However, based on terms of average financing, cluster 3 is the best cluster for it has a financing level of 11.2 trillion IDR. It exceeds the average financing in other clusters which are under 10 trillion IDR.

Information on deposit funds is also highlighted in table 5. Cluster 2 has the lowest minimum deposit funds. On the contrary, the highest minimum deposit funds is owned by cluster 3 . The maximum deposit funds exists in cluster 2 with a fantastic value of 134.7 trillion IDR. It shows that public provides a very large financial support to cluster 2 . However, if we look at the 
average of deposit funds, cluster 3 then is the most powerful cluster because it can achieve 10.8 trillion IDR.

Hence, related to the report mentioned in table 5 each cluster has weak and strength points. Cluster 2 has the lowest total assets, financing and deposit funds levels. But at the same time, cluster 2 is the owner of the most maximum of the three variables. There are not outstanding variables in cluster 1 but related to maximum value of the three variables, cluster 1 is better than cluster 3. The highest cluster is the most superior on the average values of the three variables. However, the members of this cluster are the least among all clusters.

\section{Correlation analysis}

The relationship between Islamic bank assets and number of poor people was analyzed using the pair-wise correlation of Spearman and Kendall. In line with Tumminello's research project (2010), our hierarchical cluster analysis results serve as a means to classify the correlation analysis. The correlation analysis was divided and applied in three existing clusters. To highlight cluster members whose level of correlation are significant, the correlation value of other cluster members that do not reach the significance of expected negative correlation was not deliberately displayed. However, it can be seen completely in appendix 1-3.

\section{Cluster 1}

Appendix 1 describes the results of Spearman and Kendall correlations of cluster 1 . Of the 10 provinces observed, only a few passed the significance test. In terms of the relation between the number of the poor and the assets, $40 \%$ of provinces are significant according to the Spearman correlation test and $50 \%$ of provinces are significant according to the Kendall correlation test, with the average correlation coefficients of -.809 of Spearman and -.642 of Kendall. NTB becomes the best province according to the correlation test of Spearman

Economica: Jurnal Ekonomi Islam - Volume 10, Nomor 2 (2019) https://journal.walisongo.ac.id/index.php/economica 
$(\mathrm{r}=-.857, \mathrm{p}$-value $=.007)$ and Kendall $(\mathrm{r}=-.786$, $\mathrm{p}$-value $=.006)$. It indicates that the level of negative correlation between Islamic bank assets and poverty in NTB is high (in accordance with Kendall parameters). Even though, according to Spearman's parameters it is quite perfect. Every time the Islamic bank assets increase in this province, the number of poverty will convincingly decrease. Although it is not as high as NTB, apparently West Java, Aceh, Lampung, and North Sumatra also experienced the same thing. Unfortunately, it does not occur to other provinces except them.

Appendix 1 also describes the negative correlation between deposit funds and the number of poor people in cluster 1 . Spearman correlation test results shows $50 \%$ of provinces have significant correlation value, while Kendall correlation test shows only $40 \%$ of provinces. Both the Spearman correlation test results ( $r=-.976$, $p$-value $=.000)$ and Kendall $(r=-.929$, $p$-value $=.001$ ) prove that NTB is the best province. This achievement is consistent with the previous NTB achievements, but this trend is not followed by other provinces. Although as a whole the averages of significant negative correlation level are -833 of Spearman and -.732 of Kendall, only half of cluster 1 members own the value.

The negative correlation between financing and number of the poor in cluster 1 is also described in Appendix 1. Spearman correlation test results show that only $50 \%$ of provinces are significant, while Kendall correlation test is superior because it shows that $60 \%$ of provinces are significant. NTB remains a champion in this cluster as it excels in Spearman's correlation test $(\mathrm{r}=-.976$, $\mathrm{p}$-value $=.000)$ and Kendall $(\mathrm{r}=-.929$, $\mathrm{p}$-value $=.001)$. With a perfect correlation value, any increase and decrease in the number of Islamic banks assets in NTB will easily change the structure of poverty. Unfortunately, this perfect achievement does not occur in other members of cluster 1. 
Do Islamic Bank Asset Help Reducing...

\section{Cluster 2}

The results of the correlation analysis of cluster 2 can be read clearly in Appendix 2. In this cluster the number of provinces with significant correlation values for all variables varies slightly. In accordance with relationship between assets and number of the poor, the results of Spearman and Kendall correlation test show that only $24 \%$ of provinces have significant relationships. According to the Spearman parameter, West Papua is the best province in this cluster $(\mathrm{r}=-929, \mathrm{p}$-value $=.001)$. Meanwhile, according to parameters of Kendall, North Maluku and West Papua are equally in the highest position. Both provinces results in the same correlation value $(r=-$ .857, $\mathrm{p}$-value $=.003$ ).

Similar conditions also occur in the relationship between deposit funds and number of the poor showing only $24 \%$ of provinces have significant negative correlation values. The situation explains that in the majority of cluster 2 members deposit funds changes do not alter the structure of poverty except in West Sumatra, Central Sulawesi, Gorontalo, Maluku, North Maluku and West Papua. In those provinces, changes in deposit funds can alter the structure of poverty to be better. It is proved by their achievements that are able to achieve negative correlation averages of -.854 (Spearman) and -.728 (Kendall).

Meanwhile, in the relationship between financing and number of the poor, apparently only 33\% (Spearman) and 28\% (Kendall) of the total provinces are able to meet the requirements of negative significance correlation. It tells us that in most of cluster 2 members, financing is not able to recover the poverty condition properly. Though financing is the only instrument that can be implemented directly to Islamic banks in alleviating poverty (Adnan and Ajija, 2015). Uniquely, in this correlation category West Papua is an exception, because it does not pass the test of negative correlation significance. Yogyakarta deserves an appreciation because it is able to achieve 
a perfect negative correlation level in both categories of Spearman $(r=-.976$, $\mathrm{p}$-value $=.000)$ and Kendall $(\mathrm{r}=-.929$, $\mathrm{p}$-value $=.001)$.

\section{Cluster 3}

Cluster 3, as can be seen in Appendix 3, is the best cluster in the correlation test between Islamic bank assets and number of the poor. In contrast, this cluster has the highest number of poor people (an average of 5.3 million people). In this cluster, $100 \%$ of provinces passed the significance test. Furthermore, all the coefficient average of negative correlations (Spearman and Kendall) generated by every province in this cluster is perfect. It can be proved, firstly, by looking at the negative relationship between total assets and number of poor people. In this category, Central and East Java as cluster 3 members, produced a very high correlation average $(r=-.976)$. Both provinces also produced very high significance values in both categories of Spearman ( $p$ value $=0.000)$ and Kendall ( $p$-value $=0.001)$. The results indicate that any change in total assets of Islamic bank in cluster 3 will reduce the poverty level perfectly. Conversely, an increase in poverty results in a decline in total assets of Islamic banks.

Similar results can be seen on the relationships between deposit funds and number of the poor. The average relationship of these two variables is perfect both on the averages of Spearman (-.988) and Kendall (-.964). The best province is Central Java because it is able to achieve perfect correlation coefficients $(t=-1,000$, p-value $=0.000)$ in both Spearman and Kendall correlations. It means that any change in deposit funds value of Islamic bank in Central Java can definitely reduce the poverty. Although the change is not as high as Central Java, East Java also shows the same trend.

Cluster 3 also shows excellent relationships between financing and number of poor people. It is indicated by the average value of perfect negative correlation according to both parameters of Spearman (-.976) and Kendall (.929). Undoubtedly, financing in this cluster is very powerful in alleviating 
poverty. Central Java remains in the best position, because it keeps being perfect $(\mathrm{t}=-1,000$, $\mathrm{p}$-value $=0.000)$ in accordance with both parameters of Spearman and Kendall. Central Java becomes the best example in poverty alleviation.

\section{Discussion}

In the context of this study, when the relationship between Islamic bank assets and poverty is only comprehended in one group of data, the two variables have no significant relationship. However, when it is divided into the poverty clusters of low, moderate, and high, it will be easy to find a cluster with a very significant relationship. The findings suggest that the lower the poverty in a cluster is, as measured by the number of poor people, the lower the percentage of provinces with significant relationships will be. However, the higher the poverty in a cluster is, the higher the percentage of provinces with significant relationships will be. It generates the successful of this research, which also fills the void of literature that specifically addresses the relationship of these two variables.

In low poverty cluster (cluster 2), Islamic bank assets are not very significant in helping poverty alleviation. In all relations categories between assets and Islamic bank, only $24-33 \%$ of provinces have significant negative relationships. The rest of provinces show positive or even in significant negative relationship. It indicates that when the total assets, deposit funds, and financing of Islamic banks in most provinces of cluster 2 increase, the increase will not alter the structure of poverty and vice versa. When the poverty decreases, the decrease also will not increase the indicator of all these variables. Because in cluster 2 the issue of poverty is not very strong, the maslaha theory (Cebeci and Hassan, 2012) and Islamic poverty alleviation (Dusuki and Choudhury, 2008; Rahman, 2010; Abbas and Shirazi, 2015; Adnan and Ajija, 2015; Aziz and Bin Mohamad, 2016; Rashid and Intartaglia, 2017) cannot be fully applied.

Economica: Jurnal Ekonomi Islam - Volume 10, Nomor 2 (2019) 
Muhammad Muflih

Cluster with moderate number of the poor (cluster 1) appears to be better than the previous clusters, as $40-60 \%$ of their members have strong implications for poverty change. It means that any kind of Islamic bank assets utilization in cluster 1 leads to poverty reduction in half of its members. Although the theory of maslaha (Cebeci and Hassan, 2012) and Islamic poverty alleviation (Dusuki and Choudhury, 2008; Rahman, 2010; Abbas and Shirazi, 2015; Adnan and Ajija, 2015; Aziz and Bin Mohamad, 2016; Rashid and Intartaglia, 2017) are not entirely relevant in this cluster, at least it is implementable in a half-member of this cluster.

The usage of Islamic bank assets becomes the easiest way to be used in alleviating poverty in clusters with very high poverty (cluster 3). By having $100 \%$ of provinces with significant negative correlation levels, even perfect, then the increases of total assets, deposit funds, and financing in Islamic banks in cluster 3 will reduce the poverty effectively. The poverty level reduction occurs due to the use of funds coming from pure investment. Moreover, source of social investment funds also accelerates the poverty level reduction in this cluster. It is in accordance with findings (Hassan, 2014). These findings reinforce the theories of maslaha (Cebeci and Hassan, 2012) and Islamic poverty alleviation (Abbas and Shirazi, 2015; Adnan and Ajija, 2015; Aziz and Bin Mohamad, 2016; Dusuki and Choudhury, 2008; Rahman, 2010; Rashid and Intartaglia, 2017). It also legitimizes the view that in regions where poverty is high, the contribution of Islamic bank is needed (Dusuki, 2008). Assets, deposit funds, and financing are instruments that can help to overcome this problem.

In a theoretical perspective, this research succeeded in reconstructing the Islamic poverty reduction theory. In this regard, it can be said that the relationship of Islamic bank assets and poverty cannot be generalized to all regions (Dusuki and Choudhury, 2008; Rahman, 2010; Abbas and Shirazi, 2015; Adnan and Ajija, 2015; Aziz and Bin Mohamad, 2016; Rashid and Intartaglia, 2017) due to the evidence found in this study showing that the 
assets of Islamic bank help alleviating poverty effectively only in regions whose poverty level are high. The reconstruction also mentions that the success of Islamic banks in alleviating poverty is not only measured by products that are created (Adnan and Ajija, 2015; Rahman, 2010) and by quantity of funds (Aziz and Bin Mohamad, 2016) issued by banks but it is also measured according to the level of poverty in a region. It means that to reach the target of poverty alleviation more appropriately clustering method is needed by Islamic banks.

From a managerial perspective, this study reveals the importance of local poverty mapping to improve the success of Islamic banks in alleviating poverty. Findings of this study imply three things. Firstly, in regions with low and moderate poverty levels, the relations between Islamic bank assets and poverty alleviation are not negatively significant. Therefore, to ensure that poverty alleviation can be done well, the Islamic banks in these two regions need to improve their asset utilization strategies so that the poor can really feel the benefit of Islamic bank existences. Even Islamic banks should ensure that the programs designed by them are well integrated with the sources of poverty. The second, in regions with high poverty level, the assets of Islamic banks are negatively correlated with poverty alleviation. By the reason of strong correlation, social investors can increase their investment value in these regions. Third, in regions with very high poverty level, an increase in assets, Islamic deposits, and financing of Islamic banks can reduce poverty convincingly. Therefore, to narrow the network of poverty spots in these regions, poverty alleviation programs need to be sharpened.

\section{Conclusion}

In conclusion, this research shows empirical support for the relationship between Islamic bank assets and poverty in a high-poverty cluster. This finding reinforce views on the role of Islamic banks in poverty alleviation and further research is expected to develop this relationship in a better model.

Economica: Jurnal Ekonomi Islam - Volume 10, Nomor 2 (2019)

https://journal.walisongo.ac.id/index.php/economica 
Muhammad Muflih

Based on this study, we recommend that the Islamic banking industry improve the quality of assets, third party funds, and financing because of their capabilities in reducing poverty. Thus, good management of Islamic bank assets will provide enormous benefits for marginalized communities.

\section{Limitation and future research}

The first weakness of this research is related to its research data because the operational time of Islamic banks that can be used to be analyzed in this research only 8 years. In short, the available range of data causes the research not to be able to use parametric statistics. In the absence of statistical parametric requirements, this study cannot predict the influence of Islamic bank assets against poverty. To overcome the problem, the future research need to find a country whose Islamic bank data is not only completed but also has enough time span. If the prediction can be implemented, then the contribution of each value of Islamic bank assets in alleviating poverty can be known well. The second weakness of this study relates to the variables of poverty testers, since they are limited to total assets, deposit funds, and financing. In fact, there are many other forms of Islamic bank assets that can be tested. To obtain comprehensive results, future research needs to expand the scope of asset analysis of Islamic banks. This step will further clarify the advantages and disadvantages of each unit of Islamic bank assets in reducing poverty.

\section{References}

Abbas, K., Shirazi, N., 2015. The key players' perception on the role of Islamic microfinance in poverty alleviation. Journal of Islamic Accounting and Business Research 6, 244-267. https://doi.org/10.1108/JIABR-062013-0017

Adjasi, C.K.D., Osei, K.A., 2007. Poverty profile and correlates of poverty in Ghana. International Journal of Social Economics 34, 449-471. https://doi.org/10.1108/03068290710760236 
Do Islamic Bank Asset Help Reducing...

Adnan, M.A., Ajija, S.R., 2015. The effectiveness of Baitul Maal wat Tamwil in reducing poverty. Humanomics 31, 160-182. https://doi.org/10.1108/H-03-2012-0003

Amin, H., Rahim Abdul Rahman, A., Laison Sondoh, S., Magdalene Chooi Hwa, A., 2011. Determinants of customers' intention to use Islamic personal financing: The case of Malaysian Islamic banks. J Islamic Acc and Bus Res 2, 22-42. https://doi.org/10.1108/17590811111129490

Aziz, M.N., Bin Mohamad, O., 2016. Islamic social business to alleviate poverty and social inequality. International Journal of Social Economics 43, 573592. https://doi.org/10.1108/IJSE-06-2014-0129

Boukhatem, J., Ben Moussa, F., 2018. The effect of Islamic banks on GDP growth: Some evidence from selected MENA countries. Borsa Istanbul Review 18, 231-247. https://doi.org/10.1016/j.bir.2017.11.004

Boyacioglu, M.A., Kara, Y., Baykan, Ö.K., 2009. Predicting bank financial failures using neural networks, support vector machines and multivariate statistical methods: A comparative analysis in the sample of savings deposit insurance fund (SDIF) transferred banks in Turkey. Expert Systems with Applications 36, 3355-3366. https://doi.org/10.1016/j.eswa.2008.01.003

BPS, 2017. Poverty and inequality (Statistic of poverty). BPS, Jakarta.

Cebeci, I., Hassan, K., 2012. Integrating the social maslaha into Islamic finance. Accounting Research Journal 25, 166-184. https://doi.org/10.1108/10309611211290158

Chhibber, A., Nayyar, G., 2008. Pro-poor growth: explaining the cross-country variation in the growth elasticity of poverty. International Journal of Development Issues 7, 160-176. https://doi.org/10.1108/14468950810909123

DeLong, G.L., 2001. Stockholder gains from focusing versus diversifying bank mergers. Journal of Financial Economics 59, 221-252. https://doi.org/10.1016/S0304-405X(00)00086-6

Dusuki, A.W., 2008. Understanding the objectives of Islamic banking: a survey of stakeholders' perspectives. International Journal of Islamic and Middle Eastern Finance and Management 1, 132-148. https://doi.org/10.1108/17538390810880982

Economica: Jurnal Ekonomi Islam - Volume 10, Nomor 2 (2019) 
Muhammad Muflih

Dusuki, A.W., Choudhury, M.A., 2008. Banking for the poor: the role of Islamic banking in microfinance initiatives. Humanomics 24, 49-66. https://doi.org/10.1108/08288660810851469

Gounder, N., 2013. Correlates of poverty in Fiji. International Journal of Social Economics 40, 923-938. https://doi.org/10.1108/IJSE-2012-0067

Hachicha, N., Ben Amar, A., 2015. Does Islamic bank financing contribute to economic growth? The Malaysian case. I J Islam Mid East Fin and Mgt 8, 349-368. https://doi.org/10.1108/IMEFM-07-2014-0063

Hassan, A., 2015. Financial inclusion of the poor: from microcredit to Islamic microfinancial services. Humanomics 31, 354-371. https://doi.org/10.1108/H-07-2014-0051

Hassan, A., 2014. The challenge in poverty alleviation: role of Islamic microfinance and social capital. Humanomics 30, 76-90. https://doi.org/10.1108/H-10-2013-0068

Hassan, A., Harahap, S.S., 2010. Exploring corporate social responsibility disclosure: the case of Islamic banks. International Journal of Islamic and Middle Eastern Finance and Management 3, 203-227. https://doi.org/10.1108/17538391011072417

Hauke, J.M., Kossowski, T., 2011. Comparison of Values of Pearson's and Spearman's Correlation Coefficients on the Same Sets of Data. Quaestiones Geographicae 30, 87-93. https://doi.org/10.2478/v10117011-0021-1

Kamla, R., Hussain, G.R., 2013. Social reporting by Islamic banks: does social justice matter? Accounting, Auditing \& Accountability Journal 26, 911945. https://doi.org/10.1108/AAAJ-03-2013-1268

Leuz, C., Nanda, D., Wysocki, P.D., 2003. Earnings management and investor protection: an international comparison. Journal of Financial Economics 69, 505-527. https://doi.org/10.1016/S0304-405X(03)00121-1

Patro, D.K., Qi, M., Sun, X., 2013. A simple indicator of systemic risk. Journal of Financial Stability 9, 105-116. https://doi.org/10.1016/j.jfs.2012.03.002

Pratiwi, A., 2016. Islamic banking contribution in sustainable socioeconomic development in Indonesia: An epistemological approach. Humanomics 32, 98-120. https://doi.org/10.1108/H-12-2015-0085 
Rahman, A.R.A., 2010. Islamic microfinance: an ethical alternative to poverty alleviation. Humanomics 26, 284-295. https://doi.org/10.1108/08288661011090884

Rashid, A., Intartaglia, M., 2017. Financial development - does it lessen poverty? Journal of Economic Studies 44, 69-86. https://doi.org/10.1108/JES-06-2015-0111

Rashidah, A.R., Faisal, D., 2013. Challenges and solutions in Islamic microfinance. Humanomics 29, 293-306. https://doi.org/10.1108/H06-2012-0013

Risso, W.A., Carrera, E.J.S., 2012. Inequality and economic growth in China. Journal of Chinese Economic and Foreign Trade Studies 5, 80-90. https://doi.org/10.1108/17544401211233453

Sasmal, R., Sasmal, J., 2016. Public expenditure, economic growth and poverty alleviation. International Journal of Social Economics 43, 604-618. https://doi.org/10.1108/IJSE-08-2014-0161

Shahinpoor, N., 2009. The link between Islamic banking and microfinancing. International Journal of Social Economics 36, 996-1007. https://doi.org/10.1108/03068290910984777

Suzuki, Y., Miah, M.D., 2016. Altruism, reciprocity and Islamic equity finance. I J Islam Mid East Fin and Mgt 9, 205-221. https://doi.org/10.1108/IMEFM-09-2014-0091

Tumminello, M., Lillo, F., Mantegna, R.N., 2010. Correlation, hierarchies, and networks in financial markets. Journal of Economic Behavior \& Organization 75, 40-58. https://doi.org/10.1016/j.jebo.2010.01.004

Wang, X., Liu, J., Xin, X., 2009. China's rural poverty line and the determinants of rural poverty. China Agricultural Economic Review 1, 283-300. https://doi.org/10.1108/17561370910958864

Warr, P.G., 2000. Is growth good for the poor? Thailand's boom and bust. International Journal of Social Economics 27, 862-877. https://doi.org/10.1108/03068290010372180 
Muhammad Muflih

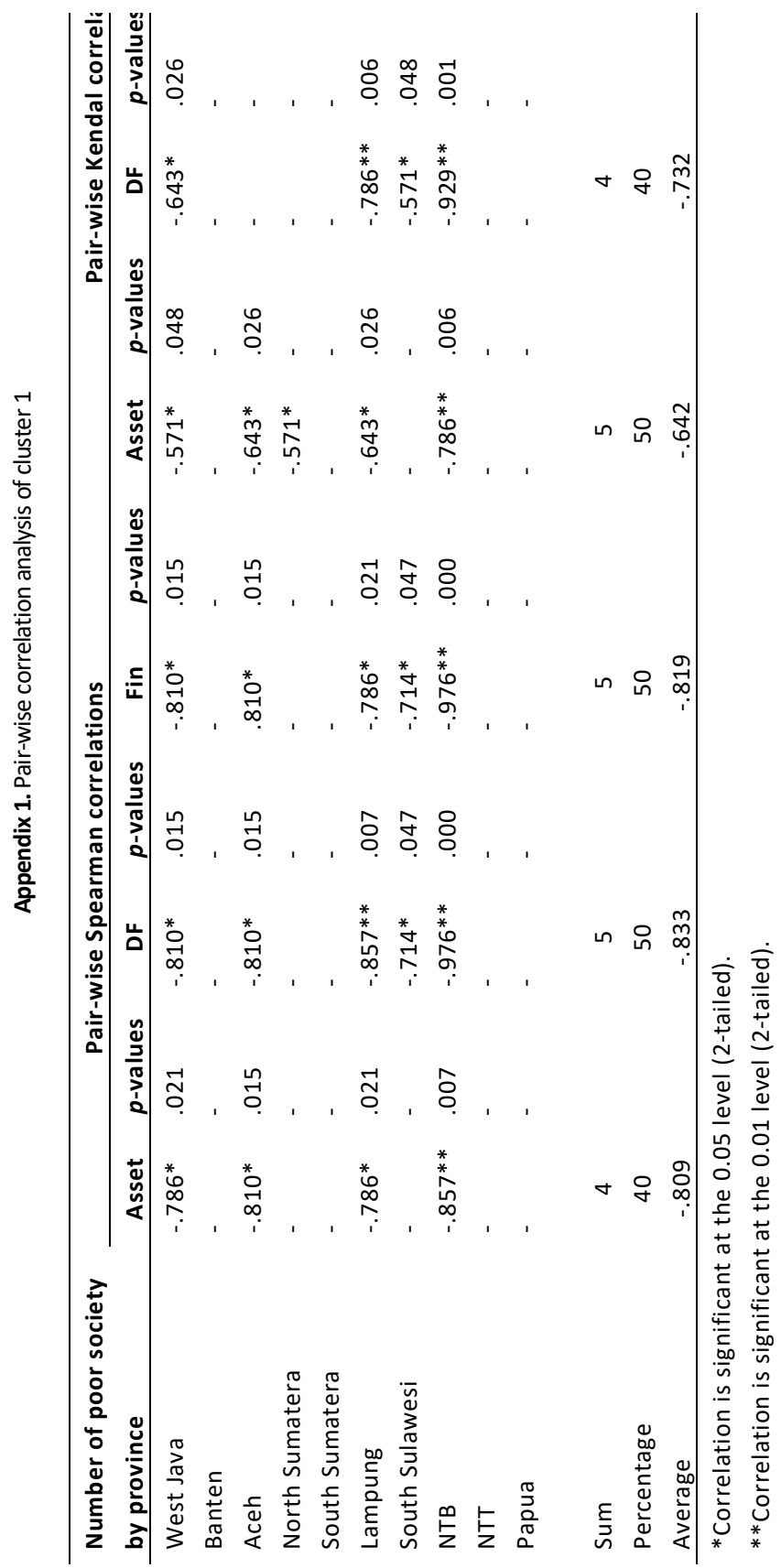


Do Islamic Bank Asset Help Reducing...

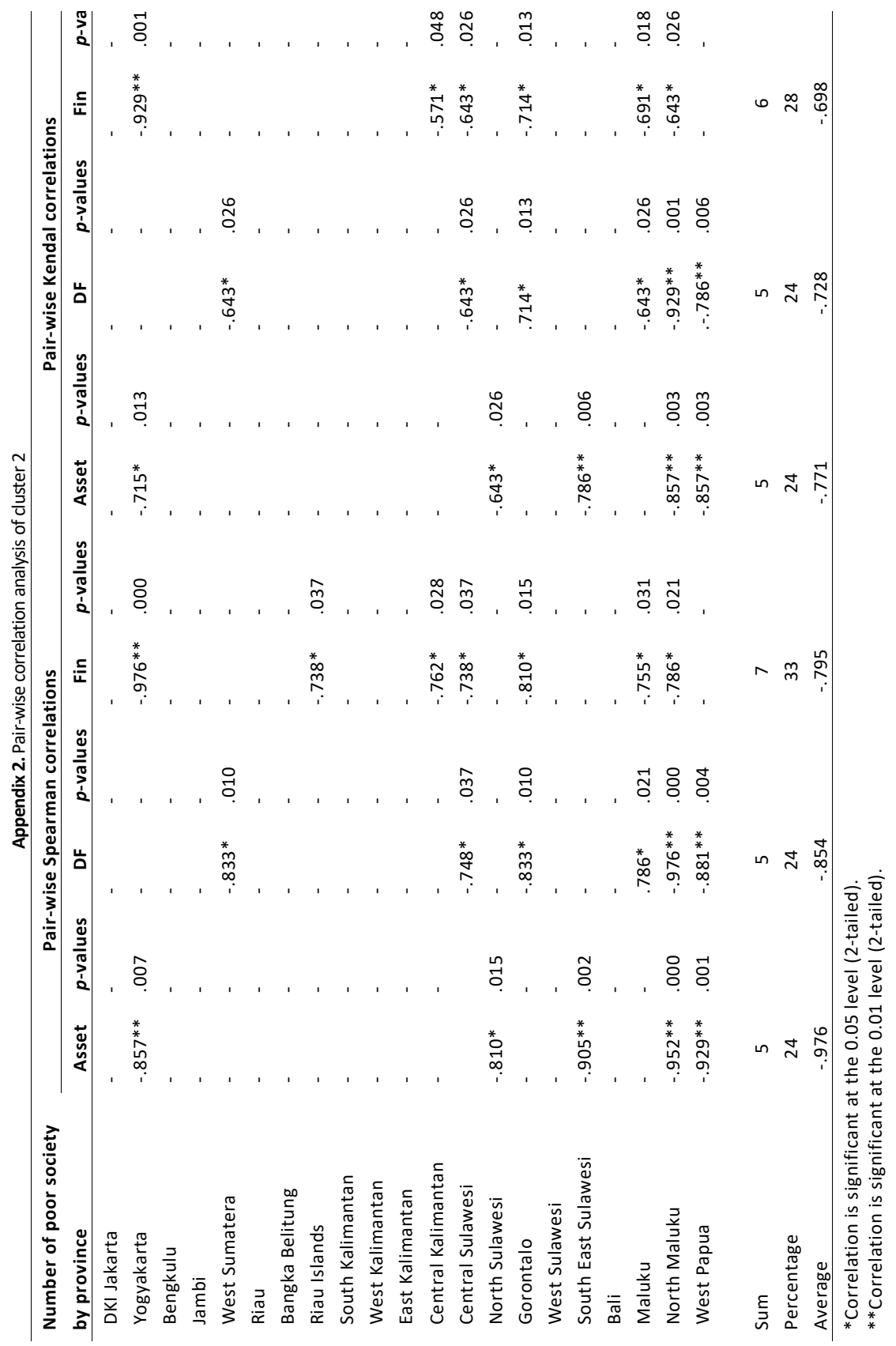

Economica: Jurnal Ekonomi Islam - Volume 10, Nomor 2 (2019)

https://journal.walisongo.ac.id/index.php/economica 
Muhammad Muflih

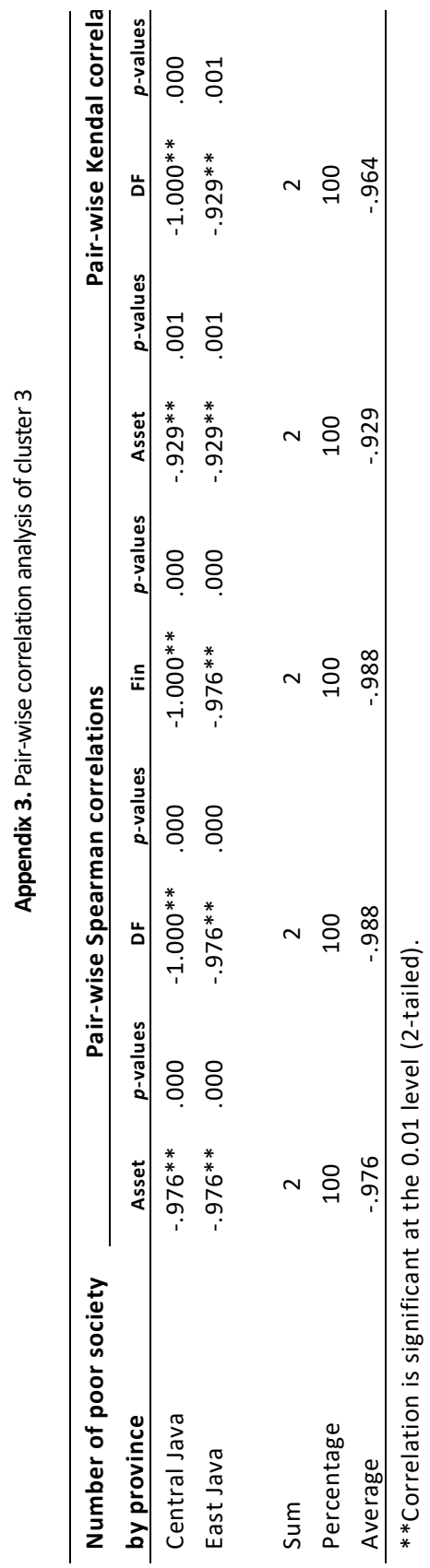

